\title{
Is Don Quixote a Symbol of Resistance or of Totalitarianism?
}

\begin{abstract}
Is Don Quixote a Symbol of Resistance or of Totalitarianism? This paper focuses on analyzing visual representations of Don Quixote in Central and Eastern European films produced during the Soviet and post-Soviet periods: the animated cartoon Don Kihote created in 1961 by Croatian director Vlado Kristl: a TV episode, Don Quixote and His Bodyguard, by Viktor Shenderovich (1995); and the feature film Don Quixote Returns by Vasiliy Livanov (1997). The image of Don Quixote is interpreted in the paper as a cultural myth used as a symbol both of resistance and of totalitarianism. This ambivalence of the quixotic myth is studied through the prism of trauma theory. The approach suggested by the author of the paper explains the popularity of Cervantes's character in totalitarian and post-totalitarian culture and reveals the complicated dynamics of liberation from slavery and the search for freedom in Central and Eastern Europe.
\end{abstract}

Keywords: resistance, totalitarianism, The Quixote, quixotic myth, visual representation, totalitarian trauma

\section{Introduction}

In this paper different ways of interpreting Don Quixote's image, as either a symbol of resistance or of totalitarianism, will be done through the lens of films based on Cervantes's novel. The study will especially focus on three films: the animated cartoon Don Kihote created in 1961 by Croatian director Vlado Kristl; the TV episode Дон Кихот и его телохранитель (Don Quixote and His Bodyguard) by Viktor

Address: Petro Mohyla Black Sea State University, 68 Desantnykiv St., 10, Mykolayiv 54003 Ukraine. E-mail: oleksandrpronkevych@yahoo.com. 
Shenderovich (1995); and the feature film Дон Кихот возвращается (Don Quixote Returns) by Vasiliy Livanov (1997). I have chosen television and cinema because they are used in constructing power relations in society through the use of cultural imagery. Thus, the paper is not a philological study of the novel but a reading of the quixotic myth in visual arts.

By the phrase "quixotic myth" Anthony Close ${ }^{1}$, Vsevolod Bagno ${ }^{2}$, Jorge Latorre ${ }^{3}$ and others understand an independent, autonomous existence of the characters in Cervantes's novel found in other works of art, ideological texts, and mass media. Svetlana Piskunova argues that

In its further life Cervantes's creation continued its existence in two ways: 1) it was extracted (together with what L. Pinskiy called "the quixotic situation") by writers and representatives of other arts from the novel, from Don Quixote as a work of verbal art (H. Hatzfeld), which was produced by Cervantes with collaboration with the implicit "ideal" reader-interlocutor; and 2) it stimulated the development of the genre innovations started by Cervantes the novelist ${ }^{4}$.

It makes sense to speak of The Quixote as two books written in 1605 and 1615 and of the character Don Quixote and others as cultural myths. Like other "enduring cultural images", such as Don Juan, Hamlet, Faust, etc., Don Quixote, Sancho Panza, and Dulcinea leave the novel and begin their new lives as protagonists of other prose works, poems, dramas, films, sculptures, paintings, political discourses, and in everyday life. They become, in the end, an integral part of the collective unconscious of individuals, nations, and peoples. They are converted into symbols, which represent a wide spectrum of abstract notions, concepts, and everyday behavior, in this particular case, into symbols of resistance and of totalitarianism.

$\mathrm{V}$. Bagno has spent much effort defining the "quixotic myth". The researcher interprets the concept in several meanings. First, he speaks about a new story (or stories) telling of the adventures of the character, who is not necessarily named Don Quixote and does not look like the hidalgo from La Mancha but behaves like him and is called Don Quixote by others. The most important feature of "the quixotic situation" (the concept was coined by Leonid Pinskiy, as mentioned above) is a conflict between Dream and Reality in the human mind. Each new epoch brings its own Don Quixotes.

First, according to V. Bagno, the mythic Don Quixote is better known to the world-wide audience than the original character in the novel. Evidence of the popularity of the quixotic myth is the fact that people who have never read the book easily identify a specific type of man as Don Quixote. The many "quixotic stories" (literary,

1 A. Close, The Romantic Approach to Don Quijote (A Critical History of the Romantic Tradition in 'Quixote' Criticism), London 1978, p. 148.

2 В. Багно, Дон Кихот в России и русское донкихотство, Москва 2009, p. 8.

3 J. Latorre, "El mito de El Quijote y la nueva Europa", [in:] El telón rasgado. El Quijote como puente cultural con el mundo soviético y postsoviético, ed. J. Latorre, A. Martínez IIlán, O. Pronkevich, Pamplona 2015, p. 13.

${ }^{4}$ С. Пискунова, Энииклопедия литературных произведеници, Москва 1998, р. 155. 
cinematographic, cultural) produce quixotic discourse, or "an international quixotic tradition".

Second, V. Bagno also believes Don Quixote and other characters become myths because, once extracted from the novel, they become symbolic reincarnations of archetypes rooted in the collective unconscious. As A. Close points out, this approach to reading and interpreting The Quixote was suggested by German Romantics and developed by such famous Spanish thinkers as Miguel de Unamuno and José Ortega y Gasset. In particular, V. Bagno explains the popularity of Don Quixote in Russian culture by the fact that Cervantes's protagonist can be inscribed "in archetypal models, which define Russian consciousness, such as the rebel, the impostor, the wanderer, and the superfluous man"5. Developing this approach suggested by V. Bagno one can find traces of other archetypes (the Hero, the Caregiver, the Explorer, the Lover, the Creator, the Sage, and others) derived from the character of Don Quixote.

Third, V. Bagno and Maria Koreneva stress that "Don Quixote" is a name which has come to mean certain types of behavior of individuals, countries, and nations. There are other words or names capable of producing similar phenomena. Examples are "Machiavelli", "Wagner", "de Sade", "Masoch", "Don Juan", "Hamlet", etc. These references give life to abstract nouns, which refer to cultural trends or to approaches to creating works of art or life-styles. Among them are "Machiavellianism", "Wagnerianism", "Don Juanism", "Byronism" and others. From the very beginning such a name is used to describe a certain cultural phenomenon and after a while it transforms into an "independent vital program, a model of life" 6 . Without any doubt, Don Quixote, Sancho Panza, Dulcinea, and even the author, Cervantes himself, belong to this category of word-progenitors, when used as patterns of social behavior and creativity.

\section{A Don Quixote of resistance and of totalitarianism seen through the prism of trauma theory}

The culture of resistance includes a wide range of images and symbols which serve as identification signs and models of behavior for those who fight against oppressive regimes. One of them is Don Quixote, the protagonist from the famous novel by Miguel de Cervantes. Many representatives of the dissident movement in the USSR and other socialist countries were viewed as Don Quixotes because they attacked windmills - meaning the repressive reality of the communist states. In his mem-

5 В. Багно, Дон Кихот в России и русское донкихотство, Москва 2009, р. 219.

${ }^{6}$ В. Багно, М. Коренева, Вожди умов и моды. Чужое имя как наследуемая модель жизни, Санкт Петербург 2003, р. 6. 
oirs Leonid Litinski compares Andrey Sakharov to Don Quixote ${ }^{7}$. The Ukrainian nationalist intellectuals of the 1960s and 1970s are often referred to as "the Quixotic generation" (Ivan Svitlychnyi, Yevhen Sverstiuk, Mykola Lukash, even Vasyl Stus). Polish intellectual Jerzy Giedroyc was called quixotic when in 1947, just after the Yalta and Potsdam conferences, he declared that without an independent Ukraine there would be no independent Poland. Other examples of calling rebels in society "quixotic" can be easily found in human history.

At the same time, paradoxically, Don Quixote is a symbol of totalitarianism. As V. Bagno points out, the quintessence of the quixotic worldview is a Utopian program ${ }^{8}$, based on a fanatical faith in the "correctness" of what Don Quixote does. In this case the term "Utopia" is interpreted metaphorically and derogatively as a synonym of an ideology which is to be implemented into practice in spite of common sense. As V. Bagno discusses, Andrey Platonov in his novel Chevengur was one of the first to point to this negative aspect of bolshevism as a totalitarian "quixotic experiment".

"We can interpret the novel as a fable about Don Quixotes, about fanatics of humanism, who have taken power" 9 . In totalitarian and anti-totalitarian propaganda the name "Don Quixote" is often used as a synonym for both Lenin and Hitler, although the former was indifferent to Cervantes's character and the latter did not like the book at all. There are cases when Don Quixotes of resistance become rulers, and turn out to be Don Quixotes of totalitarianism. The most famous example of this transformation is Che Guevara, who compared himself to Don Quixote. Paul Berman stresses that

Che was a totalitarian. He achieved nothing but disaster. [...] He presided over the Cuban Revolution's first firing squads. He founded Cuba's "labor camp" system - the system that was eventually employed to incarcerate gays, dissidents, and AIDS victims. To get himself killed, and to get a lot of other people killed, was central to Che's imagination ${ }^{10}$.

The ability of Don Quixote to represent mutually exclusive ideals and beliefs is a well-known fact. This is rooted in the ambivalence of Cervantes's book. The protagonist of the novel is full of noble intentions but his fanaticism makes him uncritical about his deeds. He is naïve and attractive, on the one hand, and dangerous and threatening, on the other. As a result, the image is open to diverse interpretations. This ambivalence is constantly used by the creators of global quixotic myths in order to convert the image of Don Quixote into ideologies which contradict each other.

7 Л. Бурмистрова (ред.), Он выезжает из другого века... Дон Кихот в России, Москва 2006, pp. 313-314.

8 V. Bagno, "El utopismo como base de la mentalidad quijotesca y del quijotismo mundial", Asociación Internacional de Hispanistas. Actas 1995, no. XII pp. 28-32.

9 В. Багно, Дон Кихот в России и русское донкихотство, Москва 2009, р. 166.

10 P. Berman, "The Cult of Che. Don't Applaud The Motocycle Diaries", Slate Magazine 2004/09, http://www.slate.com/articles/arts/culturebox/2004/09/the_cult_of_che.html (access: 14.10.2015). 
Javier Blasco describes this practice in Spanish culture of the 19th-20th centuries as something obsessive and even annoying and compares Don Quixote to "a catch-all figure to reflect the values with which thinkers wish to identify themselves ideologically"11.

The question of how Don Quixote can be easily adjusted to any ideological doctrine or artistic practice is a subject of separate research. Here I would like to contribute to solving this problem by applying trauma theory in order to explain the mechanism of using the name of Don Quixote as a symbol both of resistance and of totalitarianism in the cultures of the former "socialist" and current "postsocialist world". In my opinion, this methodological approach is relevant because in many cases the so-called "quixotic revolts" of the dissidents, on the one hand, and the totalitarian quixotic manias of communist ideologists and leaders, on the other, result from traumas, physical, moral, or cultural, caused by state violence during the communist era and the social catastrophes which followed the collapse of the communist system.

In this paper I depart from Geoffrey Hartman's idea, who argues that "Trauma Study in the arts explores the relation between psychic wounds and signification"12. By "trauma" I understand an extremely painful experience which changes the self of the individual. Thus, trauma is the kind of injury which produces a profound effect on memory, disrupts communication of the disturbing experience and leads to "the sense of self-division" or, in other words, to problems with "constructions of identity" 13 .

The Quixote, the book written by Cervantes, is full of violence and descriptions of injuries of all types. Not all of them can be defined as traumas in the strict meaning of the term but their consequences for the protagonist are serious, if not fatal. One of the main problems is whether we can consider Don Quixote's insanity the result of traumatic experience. My answer is positive because his "innocent" hobby of reading books of chivalry at night proves to be very painful: he cannot sleep and obsessive reading destroys his nervous system. This provokes a total transformation of his self: he changes his name, chooses for himself a new identity and starts his quest. His mental disorder generates his messianic dream which is ambivalent and dangerous. Implementing his "perfect" dream of the Golden Age injures and traumatizes people. There are many instances in the book telling about injuries or traumas leading to tragic consequences: the amorous insanity which "kills" Crisóstomo; the impertinent curiosity of Anselmo, and others. At the same time, Don Quixote himself is constantly injured (physically and morally) by other characters, especially in

11 J. Blasco, "La Vida de don Quijote y Sancho o lo que habría ocurrido si don Quijote hubiese en tiempo de Miguel de Unamuno vuelto al mundo", Letras hispanas 2004, no.1, p. 55.

12 G. Hartman, "Trauma within the Limits of Literature", European Journal of English Studies 7, 2003, no. 3, p. 257.

13 C. Stocks, "Trauma Theory and the Singular Self: Rethinking Extreme Experiences in the Light of Cross Cultural Identity", Textual Practice 21, 2007, no. 1, p. 71. 
Part II of Cervantes's book. By then everyone has read about the knight's previous adventures, and Don Quixote and his squire are involved in numerous humiliating "theatrical" manipulations (pranks) which look like "sequential trauma". The ending of this "treatment" is sad. Don Quixote is defeated by Sansón Carrasco and experiences a real "trauma" which ends his quest and destroys his personality. Don Quixote does not have the energy to work through this trauma, returns to his original identity and dies of melancholia.

When speaking about the quixotic myth in communist countries of Central and Eastern Europe it makes sense to use the term "totalitarian trauma", by which I mean the damage to the mental and physical health of individuals caused by the socialist way of life. The great revolutionary changes were designed as a bloody experiment to construct a new kind of man. This anti-human project of social and cultural engineering led to civil wars, purges, World War II, and punishment of dissidents. The disintegration of the socialist camp and collapse of the USSR were followed by a post-totalitarian trauma provoked by economic hardship, destruction of families and lifestyles, mass migrations, terrorist attacks, revolutions, and wars. It is no less profound than the totalitarian trauma. No need to say that both traumas were extremely painful experiences which have affected the minds of countless individuals in Central and Eastern Europe and have radically changed their destinies, selves and identities.

The application of concepts of totalitarian and post-totalitarian traumas to the quixotic myth in the cultures of the "socialist" and "post-socialist worlds" can help explain the phenomenon of Don Quixote as a symbol both of resistance and of totalitarianism. In the case of Don Quixote of resistance we should speak about the reaction of individuals to the traumatic intrusion of the political system into their lives. Violence and humiliation were applied to destroy the people's selves. This traumatic encounter of human beings with the repressive state was responded to through different lifestyles. Its essence is "the sacred insanity" which consists in resisting the system. It is not "insanity" in the medical meaning of the word; it is non-conformity which easily connects to the paradigm of the quixotic myth. This blocks negative consequences of the totalitarian trauma from the individual's self. This type of behavior can be observed in the story of the Algerian captive from The Quixote which contains the image of Saavedra, the writer himself, who suffered for five years the traumatizing experience of slavery. His way of coping with the trauma was stoic resistance and attempts to liberate himself and his comrades. Like Saavedra from the inserted novella about the Algerian captive, those representatives of quixotic consciousness against a totalitarian age look upon resistance as the only acceptable way of working through the trauma caused to their bodies and minds by repressive political regimes.

However, as has been stated above, both history and culture contain Don Quixotes of totalitarianism. Their existence can also be explained in terms of trauma theory. First, quixotic behavior results from the inability of the individual to heal 
the trauma caused by individual (domestic, sexual, etc.) and state violence. In this case he/she compensates for his/her painful experiences by imitating the repressive practices and ideologies which have destroyed his/her self in order to guarantee his/ her absolute power. Second, the post-totalitarian era also produces Don Quixotes of a totalitarian (or authoritarian) type: they are so traumatized by the aftermath of the collapse of the communist system that they see a strategy of healing their real and invented injuries in a return to the authoritarian (or totalitarian) paradigm of topdown ruling, decision-making and communicating.

\section{A Don Quixote of resistance - Don Kihote, a film by Vlado Kristl}

The animated cartoon Don Kihote was made by Vlado Kristl in 1961 and tells about the existential situation of an individual repressed by the ruthless state. The film is not an adaptation of Cervantes's novel but a free interpretation of the quixotic myth. Vlado Kristl is an avant-garde abstract artist, a film director, and a poet whose works are stylistically and philosophically engaged "with many of the most significant artistic and political developments of the twentieth century"14. His cinematographic parable about Don Quixote and Sancho Panza was created in an atmosphere of non-conformist intellectuals' confrontation with Tito's regime. Vlado Kristl's next two films The General (1962) and Arme Leute (1963) critiqued the communist system and were prohibited by censorship. As a result, the Croatian artist had to leave Yugoslavia and moved to Germany. In this context it is clear that Vlado Kristl took an interest in the figure of Don Quixote as a symbol of resistance against totalitarianism.

Non-conformity is expressed in Kristl's representation of characters and setting. The form of the animated cartoon film allowed the artist to use his experience which he had gained in the field of abstract art. The characters are "drawn with simple lines which resemble well-known images: a spear, a helmet, and a beard. The squire, Sancho Panza, is represented by a small black ball, and a tree branch. The minimalist style used throughout this animated cartoon, enchants us with its strange abstract beauty in spite of the fact that the figurative principle is reduced to the minimum"15. At the same time, Vlado Kristl's images of Don Quixote and Sancho can also be interpreted as a visual reference and parody of a famous drawing by Pablo Picasso, who was involved in the fight of Spanish intellectuals against Franco and his regime. The armies of the repressive system in the animated cartoon film are drawn as rectangular units consisting of small squares, white spots, and anthropomorphic and mechanical objects. These armies pursue the rebels in order to kill them.

14 E. Ritchel, "From Painting to Film: Rediscovering the Work of Vlado Kristl", Ikon Arts Foundation, http://ikonartsfoundation.org/vladokristl/ (access: 07.08.2016).

15 E. de La Rosa, "Don Quijote se anima", [in:] Cervantes en imágenes. Donde se cuenta cómo el cine y la televisión evocaron su vida y su obra, coord. por E. de la Rosa, L. M. González y P. Medina, Alcalá de Henares 2005, p. 49. 
The animated cartoon film depicts traumas which a non-conformist individual experiences under a totalitarian regime. One of the most effective traumatizing tools of the communist state is the threat of repressions. Vlado Kristl gives special attention to this aspect of "indoctrinating the masses". The flow of images is accompanied with sharp unpleasant sounds which recall NKVD and Gestapo practices of torture. Vlado Kristl makes the audience suffer from these sounds and the unpleasantness is intensified with noises of cars and moving troops. One can hear rifle or pistol shootings, police whistles, blowing horns and trumpets, explosions, sounds of the Morse code, rumble of people, and objects falling to the ground. The soundtrack is a metaphor of how the communist repressive apparatus produces obedient "citizens". The color range of the film also assaults the viewer with browns and bright yellows.

The repressive apparatus of the state is represented by monolithic groups of militarized and aggressive creatures. They attack Don Quixote and Sancho Panza, trying to merge them into themselves. Bodies of "servants of power" from time to time explode into pieces. Against the rebels they use artillery, aerial attack, paratroopers, and an enormous amount of military machines and equipment, all of which move chaotically across the screen. Spies follow the protagonists and transmit to their headquarters information about every step of the dissidents. Our two solitary heroes have to stand up against many armed divisions.

It is understandable that both characters, and especially the squire, are traumatized: they walk nervously, jump, and tremble. A metallic noise, which Sancho Panza produces, resembles knocking of the teeth of someone who is scared to death. Don Quixote falls down hard. In one scene he hangs his head down and looks around with eyes extended in fear. Sancho is wounded by a huge piece of rock, he has only his hat to protect himself: the spectators can see only the whites of his eyes. Then he jumps aside in order not to be killed by a car but turns into a frankfurter. Don Quixote cheers himself up by drinking a bottle of distilled water and listens to music on a gramophone. When the two characters hide in roadside ditches they turn red from horror. They escape and save themselves on a mountain top.

To sum up the plot, Don Quixote and Sancho Panza find themselves in an extremely traumatizing environment but in spite of all threats the Knight of the Sad Countenance overcomes fear and resists. From off-screen he throws the defenders of totalitarianism into the dustbin of history. The defeat provokes another outburst of rage in the system. It mobilizes new armies against Don Quixote: soldiers are about to annihilate him. At the last moment the protagonist makes an unexpected ironic gesture: surrounded by his enemies he takes an avant-garde magazine out of his pocket and begins to leaf through it. He sees a picture of Dulcinea with a huge moustache and creates a miracle: the evil armies raise the white flag and surrender. Don Quixote kisses the image of his lady. After that the camera shows windmills in sunflower fields. The armies run away from the knights. Sancho Panza is still trembling with fear while Don Quixote celebrates his victory, hanging his head down from the top of the film frame to the sad sounds of trumpets. 
The main strategy of resistance and treating the totalitarian trauma in this animated cartoon is use of irony, laughter and creative playfulness. It is the free artistic spirit which defeats the armies and helps Don Quixote overcome his fear. The animated cartoon cultivates a special type of creative insanity. Its message to the audience is: do not exaggerate fears, sufferings, pains, and physical and moral losses. These are tools of totalitarian regimes to turn all members of society into a homogeneous mass but they can be defeated by the ironic creative spirit.

\section{The knight becomes a tyrant - Don Quixote and His Bodyguard by Viktor Shenderovich}

The episode Don Quixote and His Bodyguard from Viktor Shenderovich's television program Puppets was made after the communist regime had collapsed both in the countries of Central Europe and in the republics of the former USSR. Aesthetics of the masque and the grotesque are used to show the moment when Don Quixote ceases to be the symbol of resistance and becomes the personification of totalitarianism. This transformation can be explained by the historical and cultural context in which the TV program was produced. Willingly or unwillingly, it reflects traumas caused by "the Soviet catastrophe". I mean the collapse of the USSR with its disasters: impoverishment of the masses, destroying the Russian parliament with tanks in 1993, the first Chechen war and many others. The new epoch of liberalism proved to be short and the Russian political leaders who came to power proclaiming slogans of freedom forgot them very quickly and resumed traditional totalitarian practices of ruling the country.

The part of Don Quixote is played by the puppet "Boris Yeltsin", who together with the puppet "Sancho Panza-Aleksandr Korzhakov" comes out of his house to meet the people of La Mancha. Korzhakov was Yeltsin's bodyguard and head of the president's security service. After going for a drive and eating dinner they come back home without meeting anyone. "Are you at home or again out of your mind?" (“Вы дома или опять не в себе?”), says the puppet Pablo Mercedes. Pavel Grachiov was Minister of Defense at the time, notorious for his bloody military operations in Chechnya. The audience sees traces of degradation in Don Quixote-Yeltsin's face, behavior, gestures and words. "Knight", Sancho warns, "if you do not stop daydreaming it will end in a very sad way" ("Рыцар, если Вы не перестанете фантазировать, то это закончится самым печальным образом"). Korzhakov then points to a bottle of vodka. The word "daydreaming" as used here means thinking about a new democratic Russia with European freedoms and a market economy. This quixotic "Utopia" of decent life that can never come true in Russia is the filmmaker's meaning. That is why Boris Yeltsin is not a rebel but "the Knight, who ends in a very sad way" (“Рыцарь, кончающий печальным образом”). In the past people thought Quix- 
ote-Yeltsin was a fighter against the Soviet system but they were mistaken and do not believe in him any more: "The people used to call you a knight" - says Pablo. "And what do they call me now?" - says Quixote-Yeltsin. "Something else" ("Раньше Вас народ называл рицарем”. - “А как зовет сейчас?” - “По-другомy”). Pablo remarks that he and Don Quixote and all of Russia have changed a great deal over recent years. "Much blood has been shed" - sums up Quixote-Yeltsin.

In the dialog one can find references to traumatic events of Russian history from 1990 until 1995, including the war in Chechnya, and the upcoming presidential elections of 1996, which Quixote-Yeltsin is afraid he will lose. His suggestion for how to solve the problem is an old totalitarian trick. The Constitution of Russia itself should be changed. If this is done there would be no need to reschedule the elections, because they could be cancelled.

The puppet show tells the spectators that it would be a mistake to dream about a quick transition from totalitarianism to democracy in Russia. First, top-down decision-making will survive under any circumstance, only camouflaged with cosmetic improvements of the political system, while in essence it remains unchanged. Totalitarianism is too deeply-rooted in Yeltsin's mind and in Russian reality. Second, the knights are manipulated by squires and servants. It turns out that Sancho-Korzhakov on the TV program is actually one of the puppeteers of Quixote-Yeltsin. The end result of their boss's activities will always be opposite to those intentions with which he came to power.

The dinner scene illustrates a cannibalistic aspect of totalitarianism plus traumatizing actions of Yeltsin and other Russian political elites. At the inn Don Quixote orders food named after famous Russian politicians. The menu includes such dishes as "stale Korzhik" (черствый Коржик - Aleksandr Korzhakov), "grated Zhirik" (тертый Жирик - Vladimir Zhirinovskiy), "Ziugan in tomato sauce" (Gennadiy Zuganov, leader of the Russian Communist Party), "pickled Soskovets" (маринованный Сосоковец - Oleg Soskovets, deputy prime minister of Russia), and "Barkashovka" (Aleksandr Barkashov, leader of the right wing Russian nationalist movement).

Speaking of the entrée named after Barkashov, the owner of the inn explains: "The recipe is German, the sauce is ours. It straightens the intestines so that it gets directly to the brain" "“Рецепт немецкий, соус наш. Кишечник выпрямляет так, что до мозгов достает"). Quixote-Yeltsin does not like the choice of dishes because he wants to eat more exquisite European food: Édouard Balladur or John Major. The waiter regrets the inn does not serve European food because the people of La Mancha cannot digest it.

Thus, V. Shederovich's Quixote-Yeltsin at first appears to be a figure of resistance, but turns out to be only another Russian dictator. He proved to be unable to work through the post-totalitarian trauma caused by the failure of the transition of Russia from communism to democracy. His surrealistic masque in the TV show expresses well-known features of Russian totalitarian consciousness to which politicians and the whole nation quickly returned after a short period of relative freedom. 


\section{Don Quixote of totalitarianism — Don Quixote Returns by Vasiliy Livanov}

Don Quixote Returns is a 1997 Russian-Bulgarian co-production, directed by Oleg Grigorovich and Vasiliy Livanov. Livanov, a Russian actor famed for his portrayal of Sherlock Holmes in Soviet-era screen adaptations of the works of Arthur Conan Doyle, was director, screenwriter, producer, and actor on the project. He made this film during and after the presidential election of Yeltsin for his second term. The main opponent in the race was Gennadiy Zuganov, leader of the Communist Party of Russia. The fact that Zuganov had a good chance to win produced a wave of anticommunist phobia in Russian society. Livanov's Don Quixote reflects this trend. The following statement, made by the director on the film's opening night, is explicit in this regard:

The movie title is Don Quixote Returns. What does "return" mean? First, he comes back to the screen. Second, he comes back to every one of us. "We are going to make all mankind happy". Who? We, Don Quixote and Sancho Panza. Let's say a specter has been haunting Europe ${ }^{16}$.

Don Quixote in Livanov's interpretation of the myth is no longer romantic or heroic, but ironic. The director shows Don Quixote as a totalitarian-minded old man, not as a noble hero. Don Quixote's "utopian” program in the film is a result of the character's obsessive passion for reading books of chivalry and his unsatisfied libido. This Don Quixote gratuitously attacks two German travelers, an entomologist and a botanist, and tries to force them to swear to Dulcinea's beauty without the slightest success. He is too ambitious, too irritable, and too intolerant of opinions different from his own.

Livanov's anti-totalitarian reading of the quixotic myth in his film is shown through the dialogue of the characters. This is full of communist slogans, but ironically twisted. Don Quixote even plays with Lenin's words. In the scene opening the episode in which Don Quixote and Sancho leave to look for adventures, Don Quixote says: "My delay will be like death for all humanity". The words seem to be an allusion to the words of Lenin "Промедление смерти подобно" (Delay will be like death) which he wrote on the eve of the October Revolution. Another example, "Учение Маркса всесильно, потому что оно верно" (Marx’s teaching has unlimited power because it is correct). The last part of the quote occurs in conversation between Don Quixote and Sancho at the opening of the windmill scene. Don Quixote: "Never argue with me, Sancho, because all I say is true. It is true because it is correct". The sentence imitates the syntactic structure and the main concept of Lenin's saying. This reference to Lenin works in the film as a parody of Soviet ideology.

Another strategy for undermining the totalitarian meaning of quixotic Utopias is found in the parodic film, Don Quixote, by Grigoriy Kozintsev (1957). For Livanov

16 J. Latorre, A. Martínez Illán, O. Pronkevich. “The 'Quixote’ Myth and the New Western Europe”, [in:] European Visions. Small Cinemas in Transition, ed. J. Blakenshi, T. Nagl, Bielefeld 2015, p. 272. 
this famous film was the result of presenting Cervantes's characters as building the civic religion of communism. "I do not argue with him, my understanding of the myth contradicts the version of Kozintsev because Kozintsev followed the Soviet Encyclopedia which says Don Quixote is a noble knight and Sancho Panza is a sage from the people: all the things which you cannot find in the novel"17. In Kozintsev's film one can find carnivalesque elements and scenes: Sancho's coronation as King of Barataria Island, a circus-like dance sequence at the inn, and the lion scene. But, the essential atmosphere of this film is heroic or tragic, not ironic.

Livanov's film is burlesque. Unlike in Kozintsev's film, Livanov's Don Quixote does not die at the end. On his return to La Mancha, following his defeat at the hands of Samson Carrasco, Quixote sits and stares quietly in front of a table, saddened by his failure. He clasps his hands and talks quietly to Sancho Panza. All of a sudden, the sound of chivalric music is borne to them on the wind, which Don Quixote interprets as another invitation to return to his adventures. The old man is once again transformed into a maniac ready to go out at once onto the highways and byways of the world. In the Livanov film this transformation is depicted through body language: Quixote's hair and moustache stand up on end like a lion's mane flushed for attack, and he looks around, eyes popping out of his head.

Livanov's Don Quixote Returns is an implied warning against totalitarianism and an attempt at suggesting a strategy of recovering from totalitarian trauma by mocking communist ideology, a doctrine which uses violence to achieve its goal of making humanity happy.

\section{Conclusion}

Use of the quixotic myth in films made during the communist and postcommunist period demonstrates the ambivalence of Cervantes's character. In Cervantes's novel Don Quixote is both a hero and an anti-hero. After becoming a myth, the figure of the Knight of the Sad Countenance preserves that ability to represent contradictory, often incompatible values, meanings and beliefs. This quality of the novel's Don Quixote as an ambiguous literary image explains the presence of his tragicomic figure in a wide spectrum of discourses, in particular, as discussed in this paper, a figure of both resistance and totalitarianism.

The application of trauma theory to The Quixote and the quixotic myth explains the popularity of Cervantes's character in the anti-totalitarian and post-totalitarian cultures of Central and Eastern Europe in the second half of the 20th century and beginning of the 21st. Don Quixote can be made a symbol of non-conformity, fight-

17 O. Pronkevych, "Entrevista a Vasiliy Livánov, director y actor de Don Quijote vuleve (coproducción ruso-bulgara, 1997)”, [in:] El telón rasgado. El Quijote como puente cultural con el mundo soviético y postsoviético, ed. J. Latorre, A. Martínez IIlán, O. Pronkevich, Pamplona 2015, p. 445. 
ing against the communist regime as in Vlado Kristl's animated cartoon. In it, the character becomes a political and aesthetic dissident able to cope with totalitarian trauma using imagination, irony and a strong will.

In contrast, Kozintsev's film idealizes Don Quixote, making him appear exclusively noble. In reality, the insanity of the character can lead to a totalitarian program of social, economic or cultural transformation. The study of the quixotic myth shows it is not easy to recover from totalitarian trauma because the influence of communist ideology is still strong in the countries of the former USSR, even after communism was destroyed. Don Quixotes of Viktor Shenderovich and Vasiliy Livanov point to this fact. Thus, the cinematographic adventures of Don Quixote and his squire reveal how complicated the dynamics of liberation from totalitarianism, and the search for freedom in Central and Eastern Europe are. 